\title{
Turkish Adaptation Study Of Multidimensional Observation Scale For Elderly Subjects
}

\section{Yaşl1 Bireyler İçin Çok Boyutlu Gözlem Ölçeği’nin Türkçeye Uyarlama Çalışması}

\author{
Haldun Soygür ${ }^{1}$, Veli Duyan ${ }^{2 *}$,Ergün Hasgül ${ }^{3}$, Mustafa Adıbatmaz ${ }^{4}$
}

\begin{abstract}
Introduction: The aim of this study is to adapt the Multidimensional Observation Scale for Elderly Subjects developed by Helmes, Csapo and Short (1987) to Turkish for the aged care workers. The Multidimensional Observation Scale for Elderly Subjects was developed in order to assess the psycho-social functioning of older adults. Methods: The scale has five functional domains, each consisting of eight items. There are a total of 40 items in the scale. The scale was applied to 229 older adults by two social workers who are studying in the field. There were 119 older adults who volunteered to participate in the study among 233 older adults staying in Karabük Yücel Nursing Home and Kastamonu Nursing and Rehabilitation Center and 110 older adults living with their families in Kastamonu. Results: The Cronbach Alpha values of the functional domains of the scale were found to be .89 for self-care; .85 for disorientation; .80 for depression/anxiety; .77 for irritability, and .87 for withdrawal, respectively. As a result of the confirmatory factor analysis, it was determined that the distribution of the items in the Multidimensional Observation Scale for Elderly Subjects to the subscales was similar to the distribution in the original scale. Furthermore, reliability values of the scale and its subscales are adequate. Conclusion: It is thought that the Turkish form of the scale can be used to evaluate multidimensional and determine the cognitive, psychological and social functionings of older adults who are in institutional care or live with their families in Turkey.
\end{abstract}

Key words: Elderly, functionality, multidimensional observation for elderly subjects, MOSES

\section{ÖZET}

Giriş: Bu çalışmanın amacı, Helmes, Csapo ve Short (1987) tarafından geliştirilmiş olan Yaşlı Bireyler İçin Çok Boyutlu Gözlem Ölçeğini yaşlılık alanında çalışanlar için Türkçeye uyarlamaktır. Yaşlı Bireyler İçin Çok Boyutlu Gözlem Ölçeği, psikososyal açıdan ve yaşlıların işlevselliklerini çok yönlü değerlendirmek amacıyla geliştirilmiştir. Yöntem: Ölçek her biri sekiz maddeden oluşan beş işlevsel alana sahiptir. Ölçekte toplam 40 madde bulunmaktadır. Ölçek, Karabük Yücel Huzurevi ve Kastamonu Huzurevi ve Yaşlı Bakım Rehabilitasyon Merkelerinde kayıtlı olarak yaşayan toplam 233 bireyden çalışmaya katılmaya gönüllü olan 119'u ve Kastamonu ilinde ailesi ile yaşayan 110'u olmak üzere toplam 229 yaşlı bireye, alanda çalışan iki sosyal hizmet uzmanı tarafindan uygulanmıştır. Bulgular: Ölçeğin işlevsel alanlarının Cronbach Alpha değerleri sırasıyla öz-bakım için 0,89; yönelim bozukluğu için 0,85; depresif/kaygılı duygudurum için 0,80; huzursuzluk verici davranış için 0,77 ve toplumdan uzaklaşma için 0,87 olarak bulunmuştur. Yaşlı Bireyler İçin Çok Boyutlu Gözlem Ölçeğini oluşturan maddelerin alt ölçeklere dağılımının doğrulayıcı faktör analizi sonucunda orijinal ölçekteki dağılımla benzer olduğu saptanmıştır. Ayrıca ölçeğin bütününe ve alt ölçeklerine ait güvenirlik değerleri yeterli düzeydedir. Sonuç: Ölçeğin Türkçe formunun Türkiye'de kurum bakım hizmeti alan ya da ailesiyle birlikte yaşayan yaşlı bireylerin bilişsel, psikolojik ve sosyal işlevselliklerini belirlemede ve çok boyutlu değerlendirmede kullanılabileceği düşünülmektedir.

Anahtar kelimeler: Yaşlılık, işlevsellik, yaşlı bireyler için çok boyutlu gözlem, YBİÇBGÖ

Received / Geliş tarihi: 07.04.2017, Accepted / Kabul tarihi: 23.07.2017

${ }^{\prime}$ Şizofreni Dernekleri Federasyonu Başkanı Ankara

${ }^{2}$ Ankara Üniversitesi Sağlık Bilimleri Fakültesi Sosyal Hizmet Bölümü

${ }^{3}$ Kastamonu Üniversitesi Tosya Meslek Yüksekokulu Sağlık Bakım Hizmetleri Bölümü

${ }^{4}$ Karabük Üniversitesi Sağlık Hizmetleri Meslek Yüksekokulu Dişçilik Hizmetleri Bölümü

*Address for Correspondence / Yazışma Adresi: Veli Duyan, Ankara Üniversitesi Sağlık Bilimleri Fakültesi Sosyal Hizmet Bölümü Ankara-TÜRKIYY E-mail: duyanveli@yahoo.com

Soygür H, Duyan V, Hasgül E, Adıbatmaz M. Turkısh Adaptatıon Study of Multıdımensıonal Observatıon Scale for Elderly Subjects. TJFMPC, 2017;11(3): 171-185.

DOI:10.21763/tjfmpc.336150 


\section{GíRIŞ}

Yaşlılık, yalnızca günümüze ait bir kavramı olmayıp insanoğlunun her çağda ilgisini çekmiştir. Yaşlılık konusunda söylenen ve halen elimizde bulunan birçok düşünce vardır. Aristhophanes (M.Ö. 445385) "Yaşlılık ikinci bir çocukluk dönemidir" demiştir. Bu fikre cevaben Goethe (1749-1832) "Söylenildiği gibi yaşlılık insanı çocuksu yapmaz, o bizi sadece gerçek çocuklar olarak bulur" der. Heinrich Heine (1797-1856) yaşlılık hakkında "Kendimiz bir enkaz haline gelinceye kadar enkazın ne olduğunu anlamayız" demiştir. ${ }^{1} \mathrm{Bu}$ örnekler artırılabilir. Yaşlılığın çocukluğa dönüş ya da bir enkaz olarak görüldüğü örneklere kıyasla, genel olarak yaşlılık yaşamın her alanında yaygın bir kayıp duygusunun yaşandığı bireylerin bedensel, psikolojik ve sosyal yönden bağımsızlıklarını yitirip, yeniden bağımlı duruma geçtikleri bir dönem olarak tanımlanabilir. ${ }^{2}$ Günümüzde dünyada meydana gelen teknolojik, ekonomik, sosyal ve kültürel değişimler aile yaşam kalıplarını da değiştirmektedir. Yaşlılık dönemindeki bireylerde kurum bakımı alma ya da yalnız yaşama konusundaki sosyal kabullenmeyle birlikte yaşlıların büyük bir çoğunluğu kurum bakımı almayı ya da yalnız yaşamayı tercih etmektedirler. ${ }^{3,4}$ Bunun nedenlerinden en önemlileri, eşlerin ya da yakın arkadaşların kaybı ve biyopsikososyal sağlık durumlarındaki değişiklikler sebebiyle günlük yaşam becerileriyle sosyal işlevselliklerinde kalite yönünden önemli değişiklikler yaşayabilmeleridir. ${ }^{5}$ Aile, konut ya da ekonomik durum gibi sosyal kaynakların varlığı ve etkinliği yaşlıların fonksiyonel kapasitelerini önemli oranda etkileyebilecek anahtar unsurlardır. ${ }^{6}$ Yaşam süresinin uzaması karşılaşılan sorunların çeşitliliği artmakta ve bu yeni sorunlar yeni çalışma alanlarının ortaya çıkmasına yol açmaktadır. Yaşlı sayısı arttıkça, yaşlılara yönelik bakım ve sağlık hizmetlerinin planlanması ve geliştirilmesi gereksinmesinin, ${ }^{7}$ bağımsız işlevselliğin desteklemesi için rehabilite edici hizmetlere olan ihtiyacın arttığı/artacağı ve yaşlılar ile ailelerinin sorunlarını etkili bir şekilde yönetebilmek için daha fazla psikolojik ve sosyal destek gerekeceği bilinmektedir. ${ }^{8} \mathrm{Bu}$ nedenle yaşlıların öz-bakım becerileri; zaman, kişi ve yer gibi yönelimleri;

1950
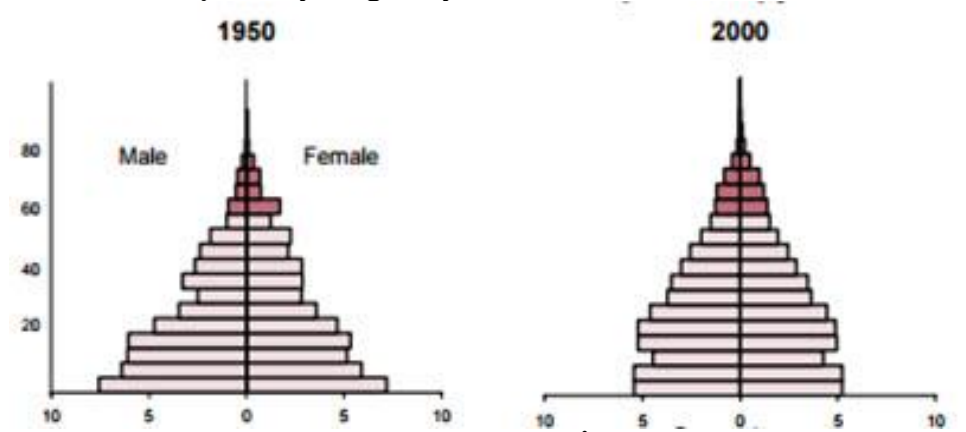

Şekil 1: Birleşmiş Milletler. Ekonomi ve Sosyal İşler Dairesi Nüfus Bölümü: Dünya Nüfus Yaşlanması 19502050. 1 depresif ve kaygılı duygudurumları; huzursuzluk verici davranışları ve toplumdan uzaklaşma durumları gibi psikososyal özelliklerinin değerlendirilmesi, yaşlılara yönelik sosyal ve sağlık sağlayabilir. ${ }^{9}$

Nüfusun yaşlanması, bir nüfusun yaş yapısının değişerek, o nüfustaki çocukların ve gençlerin payının azalması ve yaşlı insanların (60 yaş üstü veya 65 yaş üstü) payının göreceli olarak artmasıdır. ${ }^{10}$ Günümüzde sağlık alanındaki teknolojik ilerlemeler ve sağlık hizmetlerinin yaygınlaşmasıyla beraber doğum ve ölüm hızları düşerek ortalama insan ömrü uzamakta, yaşlı nüfus artmaktadır. Bu durum toplumların ekonomik, sosyal ve sağlı sorunları ile karşı karşıya kalmalarına neden olmuştur. ${ }^{11}$ Dünyada yaşlıların nüfus içinde yüzdesinin en fazla olduğu kıta, Avrupa (\%20) ve en az olduğu kıta ise (\%5) Afrika'dır. 2050 yılına gelindiğinde, Avrupa'da yaşlı nüfus oranı \%37'e çıkacağı Afrika'da \%10 olacağı tahmin edilmektedir. $^{12}$

Tufan'a göre "Türkiye'de hızlı bir kentleşme ve iç göç hareketlerinin yanı sıra, işsizlik, doğum oranlarının gerilemesi, okuryazar sayısındaki artış, ortalama yaşam süresinin uzaması, çalışan kadın sayısının artması gibi sosyolojik olgular ülkemizdeki yaşam biçimlerinin ve yaşam biçimi tercihlerinin değişmesine yol açmaktadır. Bu nedenle de Avrupa'nın en genç toplumuna sahip olan Türkiye'de yaklaşık 40 milyonluk büyük bir kitle 2030 yıl gibi kısa bir süre sonra yaşlı kategorisinde yer alacaktır. ${ }^{13}$ Türkiye İstatistik Kurumu (TÜİK) 2016 yılı verilerine göre 2016 yılında 65 yaş ve üzerinde 6.651 .503 kişi $(\% 8,3)$ varken, 2050 y1lında 19.484.834 kişinin $(\% 20,8) \quad$ olmas1 beklenmektedir. ${ }^{14}$ Yine Birleşmiş Milletler Dünya Nüfus Yaşlanması 1950-2050 çalışmasına göre Türkiye'nin yaşa göre nüfus piramidi Şekil 1'de gösterildiği gibi 1950'li yıllardaki piramit şeklinden 2050'li yıllarda dikdörtgene yakın bir şekle dönüşeceği öngörülmektedir. Nüfus piramidinin bu değişimi toplam nüfustaki yaşlı oranının hızla arttığını genç nüfusun oranının azaldığını göstermektedir. hizmetlerinin planlanmasına önemli katkılar 
Tüm dünyada olduğu gibi ülkemizde de değişmekte olan nüfus yapısı göz önüne alınarak, bu insanların gereksinimlerini karşılamaya yönelik hazırlıkların yapılması gerekmektedir. ${ }^{15}$ Dünya ve Türkiye için kaçınılmaz bir gerçek ve gelecek olan yaşlılık ile ilgili bugüne kadar, dönemin yaygın sorunlarını belirleyebilmek ve çözebilmek amacıyla birçok ölçek geliştirilmiştir. $\mathrm{Bu}$ çalışma ise huzurevlerinde ve evinde ailesiyle yaşayan yaşlıların bilişsel, psikolojik ve sosyal işlevselliklerini belirleyebilmek ve yaşlıları çok boyutlu değerlendirebilmek için alan yazına bir ölçme aracı kazandırılması açısından önemlidir. Yaşlı Bireyler İçin Çok Boyutlu Gözlem Ölçeği (YBİÇBGÖ) Londra Psikogeriyatrik Derecelendirme Ölçeğinin (LPRS) gelişimini hızlandıran boylamsal bir araştırma programından doğmuştur ve bu ölçümlerin geçerliğini ve kullanılabilirliğini geliştirmeyi amaçlamaktadır. ${ }^{16,17,18}$ Çok boyutlu ölçeklerin kısa olmaları, zaman ve etkililik açısından vakaların çoğunda tercih edilmelerini sağlamaktadır. YBİÇBGÖ’nün kısalığı ve psikometrik özellikleri çok boyutlu bir değerlendirmeye olanak vermektedir. YBİÇBGÖ teorik bilgilerin 1şı̆̆ında yaşlı bireylerde işlevselliğin başlıca alanlarını belirlemede önceki ölçme araçlarının uygulamalı faktör analizleri için geliştirilmiştir. ${ }^{18}$

\section{Amaç}

$\mathrm{Bu}$ çalışmanın amacı, Helmes, Csapo ve Short (1987) tarafından geliştirilmiş olan YBİÇBGÖ’yü (Ek 1) yaşlılık alanında çalışanlar için Türkçeye uyarlamaktır. ${ }^{18}$

\section{YÖNTEM}

\section{Çalıșma Grubu}

Ölçeğin geçerlik ve güvenirlik çalışması için Karabük Yücel Huzurevi ve Kastamonu Huzurevi ve Yaşlı Bakım Rehabilitasyon Merkezilerinde kayıtlı olarak kalan toplam 233 bireyden çalışmaya katılmaya gönüllü olan 119'unun ve Kastamonu ilinde ailesi ile birlikte ikamet eden 110 yaşlı bireyin katılımıyla, toplam 229 yaşlı bireyle görüşülmüştür. Ölçeklerin alanda çalışan iki sosyal hizmet uzmanı tarafından uygulanmıştır.

Tablo 1'de YBİÇBGÖ'nün geçerlik ve güvenirlik çalışmasına katılan yaşlıların sosyodemografik özelliklerine ilişkin bilgilere yer verilmiştir. Tablo 1'den de anlaşılacağı üzere uyarlama çalışması evrenden bir genelleme yapmaktan çok ölçeğin uygulanabileceği evreni temsil eden bir çalışma grubu üzerinde yapılmıştır. Ölçek Kastamonu ve Karabük illerinde Aile ve Sosyal Politikalar Bakanlığına bağlı huzurevlerinde ikamet eden (\%52) ve Kastamonu ilinde evinde ailesiyle yaşayan (\%48), 100'ü kadın ve 129'u erkek, yaşları 60 ile 89 arasında değişen (Ort = 71,07; SS = 5,66), 72'si evli $(\% 34,5)$, 75'i bekâr $(\% 32,8)$ ve 82 'si dul $(\% 35,8)$ olan, ögrenim ve gelir düzeyi düşük toplam 229 yaşlıya uygulanarak güvenirliği ve geçerliği belirlenmeye çalışılmıştır.

\section{Veri Toplama Süreci}

Uygulamanın yapılması ve verilerin toplanmas1 yönünde öncelikle Aile ve Sosyal Politikalar Bakanlığından ve Kastamonu ili Tosya İlçesi Kaymakamlığından resmî izin alınmıştır. Çalışma öncesinde huzurevi çalışanlarına, yaşlılara ve aile bireylerine verdikleri bilgilerin araştırma kapsamı dışında kullanılmayacağ 1 bilgisi verilmiş ve araştırmaya katılmada gönüllülük esas alınmıştır. Veri toplama araçlarının uygulanması her yaşlı birey için yaklaşık 15 dakika sürmüştür. Kurumda veri toplamaya öncelikle sosyal hizmet uzmanı olan iki araştırmacının yaşlı bireylerle yüz yüze görüşmesi, gözlemleri ve sosyodemografik bilgilerini alması ile başlanmıştır. Daha sonra araştırmacılar yaşlı bireylerden sorumlu olan ve onlara bakım veren bakım teknikerlerine, hemşirelere ve sosyal hizmet uzmanlarına her bir yaşlı birey için Çok Boyutlu Gözlem Ölçeğini uygulamıştır. Araştırmacılar evde yaşayan yaşlı bireyler için ise veri toplamayı ev ziyaretleriyle yapmışlardır. Bu amaçla araştırmacılar katılmaya gönüllü yaşlı bireyleri evlerinde ziyaret ederek hem yaşlı bireylerin kendilerinden hem de yaşlı bireylerle birlikte yaşayan aile üyelerinden verileri toplamışlardır. Veri toplama süreci yaklaşık üç ay sürmüştür.

\section{Yaşı Bireyler İçin Çok Boyutlu Gözlem Ölçeği}

\section{Tanitım}

YBİÇBGÖ Helmes, Csapo ve Short ${ }^{18}$ tarafindan yaşlıların işlevselliğini çok yönlü olarak değerlendirmek üzere hazırlanmış bir ölçme aracidir.

\section{Alt Boyutlar ve Puanlama}

40 maddeden oluşan bu ölçek her biri sekiz maddeden oluşan beş işlevsel alanı değerlendirmektedir. Bu alanlara ilişkin bilgiler aşağıda verilmiştir.

Öz-bakım (1, 2, 3, 4, 5, 6, 7, 8), Yönelim bozukluğu $(9,10,11,12,13,14,15,16)$, depresif/kayg1l duygudurum $(17,18,19,20,21,22$, $23,24)$, huzursuzluk verici davranış $(25,26,27,28$, $29,30,31,32)$ toplumdan uzaklaşma $(33,34,35,36$, 37, 38, 39, 40). Bu işlevsel alanlardan öz-bakım için yaşlı bireyin giyim kuşamı; saç, tırnak kesme, tıraş olma, diş bakımı, banyo yapma gibi öz-bakım becerileri; tuvalete çıkma, idrar ve dışkı kaçırma durumu; yatağa kendi başına yatma ve yataktan 


\begin{tabular}{|c|c|c|}
\hline Sosyodemografik Özellikler & $\mathbf{S}$ & $\%$ \\
\hline \multicolumn{3}{|l|}{ İkamet Yeri } \\
\hline Kurum bakımı & 119 & 52,00 \\
\hline Ailesi yanında & 110 & 48,00 \\
\hline \multicolumn{3}{|l|}{ Cinsiyet } \\
\hline Kadın & 100 & 43,70 \\
\hline Erkek & 129 & 56,30 \\
\hline \multicolumn{3}{|l|}{ Yaş * } \\
\hline $60-65$ & 44 & 19,20 \\
\hline $66-70$ & 97 & 42,40 \\
\hline $71-75$ & 42 & 18,30 \\
\hline $76-80$ & 29 & 12,70 \\
\hline 81 ve üzeri & 17 & 7,40 \\
\hline \multicolumn{3}{|l|}{ Medeni durum } \\
\hline Evli & 72 & 31,40 \\
\hline Bekâr & 75 & 32,80 \\
\hline Dul & 82 & 35,80 \\
\hline \multicolumn{3}{|l|}{ Öğrenim durumu } \\
\hline Okur-yazar değil & 79 & 34,50 \\
\hline Okur-yazar & 45 & 19,70 \\
\hline İlkokul & 80 & 34,90 \\
\hline Ortaokul & 18 & 7,90 \\
\hline Lise & 6 & 2,60 \\
\hline Lisansüstü & 1 & 40 \\
\hline \multicolumn{3}{|l|}{ Gelir durumu** } \\
\hline $0-500$ & 89 & 38,90 \\
\hline $501-750$ & 81 & 35,40 \\
\hline $751-1000$ & 38 & 16,60 \\
\hline 1001 ve üzeri & 21 & 9,20 \\
\hline \multicolumn{3}{|l|}{ Meslek durumu } \\
\hline Emekli & 121 & 52,80 \\
\hline Ev Hanımı & 94 & 41,00 \\
\hline Diğer (Çiftçi, İșsiz, Serbest) & 14 & 6,20 \\
\hline
\end{tabular}

$*$ Ort $=71,07 ;$ SS $=5,66 ;$ En alt - En üst $=60-89 \quad * *$ Ort $=667,47 ;$ SS $=338,99 ;$ En alt - En üst $=0-2300$

kalkma durumu; fiziksel hareketliliği; kısıtlayıcıların kullanımı değerlendirilir. Yönelim bozukluğu için yaşlı bireyin iletişimi anlaması, konuşması, yakın zamandaki olayları anımsaması, önemli geçmiş olayları anımsaması, zamanın ve bulunduğu yerin farkında olması, insanları tanıması, bina içinde yolunu bulması değerlendirilir. Depresif/kaygılı duygudurum için mutsuz ve depresif görünümü, konuşmaları ve ses tonu; endişeli ve kaygılı görünümü ve konuşmaları; inleme, iç çekme ve acı acı bağırma dışındaki ağlama sıklığı; gelecek hakkında karamsarlık durumu ve kendisiyle aşırı meşgul olma durumu değerlendirilir. Huzursuzluk verici davranış için yaşlı bireyin bakım veren kişiler ile işbirliği, bakım veren kişilerin istem ve yönergelerine uyumu, alınganlık ve huysuzluk durumu, engellenmeye karş1 tepkileri, bakım veren kişilere ve diğer insanlara sözel saldırı durumu, başkalarına fiziksel saldırı durumu, diğer insanlarla münakaşa çıkarma durumu değerlendirilir. Toplumdan uzaklaşma işlevsel alanı için ise yaşlı bireyin yalnızlığı tercih etme durumu, sosyal ilişskileri başlatma durumu, sosyal ilişki kurma girişimlerine verdiği tepkisi, diğer insanlarla arkadaşlığı, günlük olaylara ilgisi, dış çevrede olan olaylara ilgisi, bir işle meşgul olma durumu ve başkalarına yardım etme durumu değerlendirilir. Ölçek hem huzurevinde yaşayan hem de evde yaşayan yaşlı bireyler üzerinde uygulanacak şekilde düzenlenmiştir.

Ölçekteki her bir madde 0-4 arasında puanlanmaktadır. Ölçeğin 22 maddesi 4 seçenekli ve 18 maddesi ise 5 seçeneklidir. Bunun nedeni 5 seçenekli maddelerdeki son seçenek yaşlı bireyin soruyu cevaplayamayacağı ve/veya yaşlı bireye uygun olmama ihtimali düşünülerek konulmuştur. Ölçekten alınabilecek toplam en düşük puan 0 , en yüksek puan ise 138'dir. Ölçek puanının düşük olması yaşlı bireyin işlevselliğinin yüksek olduğunu, ölçek puanının yüksek olması ise yaşlı bireyin işlevselliğinin düşük olduğunu göstermektedir. 
Ölçeğin her bir maddesi aile üyeleri ve doğrudan bakım personeli gibi üçüncü şahıslar tarafından hızlı bir şekilde tamamlanabilir nitelikte ve ölçek uyumsuz davranışlar için bir tarama aracı olarak nispeten hızlı bir araçtır. ${ }^{19}$

\section{Değerlendiriciler İçin Talimatlar}

1. Ölçeği Okuyun: Yaşlıları gözlemlemeye başlamadan onların davranışlarının türlerini bilmeniz için önce ölçeğin 40 maddesini birkaç defa okuyun. Sonra aklınızda belirli bir yaşlı belirleyin ve onunla birlikte maddeleri tekrar daha ayrıntılı bir şekilde inceleyin.

2. Gözlemleme Dönemi: Yaşlı birey yalnızca gündüz vakitlerinde değerlendirilir (sabah saat 7 gibi erken saatlerden, akşam 9 gibi yaşlı birey yatağa gidene kadar). Yalnızca gözlemleme süresince gördüğünüz davranışları puanlamalısınız (ya da sana rapor edilen). Yaşlı bireyin yapmadığını düşündüğünüz ya da bu gözlemleme sürecinden önce olan davranışları puanlamayınız. Gerektiğinde görmediğiniz davranışları personele sorunuz.

3. Puanlama Formunu Doldurun: 40 maddenin her biri için yaşlı bireyi en iyi açıkladığını düşündüğünüz bir seçeneği daire içerisine alın. Bazı soruların o kurumda yaşayan yaşlı bireyler için uygun olmadığını düşünseniz bile lütfen ölçekteki tüm maddeleri cevaplamaya çalışın.

\section{Verilerin Çözümlenmesi}

Ölçeğin dil geçerliliği için uzman kanısına dayalı çeviri, ters çeviri ve bu çevirilerin tutarlılığ incelenmiştir. Güvenirliği için, (ölçekten alınan puanların tutarlılık derecesi ve ölçeğin homojenliğini belirlemek amaciyla) test-tekrar test ve ölçeği oluşturan maddelerin iç tutarlılığını veren Cronbach Alpha Katsayısı hesaplanmıştır. Ölçeği oluşturan maddelerin toplam test puanları ile korelasyonları hesaplanarak madde ayırıcılık gücü indeksleri hesaplanmıştır. Madde ayırıcılık gücü indeksleri 0,20 ve üzerinde olması kabul edilebilir ölçüt olarak alınmıştır. Her bir boyuttaki maddelerin oluşturduğu ölçeğin güvenirliği ve madde ayırıcılıkları hesapladıktan sonra, geçerlilik için doğrulayıcı faktör analizinden yararlanılmıştır. Ölçeği oluşturan beş alt boyut için 8'er madde, ölçeğin orijinalinde belirlenmiştir. $\mathrm{Bu}$ maddelerin ilgili alt boyutla uyumlu olup olmadığını belirlemek amacıyla doğrulayıcı faktör analizi yapılmıştır. Doğrulayıcı faktör analizinde ki-kare ile serbestlik derecesi oranına, hata istatistiklerine ve uyum istatistiklerine bakılmıştır.

\section{BULGULAR}

\section{Dil Geçerliği}

Orijinali İngilizce olan YBİÇBGÖ'nün Türkçe çevirisi, Ankara Üniversitesinde üç öğretim üyesi ve iki araştırma görevlisi tarafından yapılmıştır. Daha sonra bu çeviriler bir araya getirilerek hepsinin ortak yönleri aranmış ve farklılık gösteren ifadeler, çeviri yapan kişiler ile görüşülerek ortak bir cümle haline getirilmiştir. Uzman görüşüne dayanarak oluşturulan Türkçe formu, tekrar İngilizceye çevrilmiştir. Ölçeğin orijinal hali ile tekrar İngilizceye çevrilmiş hali Ankara ve Hacettepe Üniversitesinden birer akademisyene incelettirilerek, ikisi arasında farklılığın olmadığı yönünde ortak görüşe varılmıştır. Bununla birlikte ölçeğin daha kapsamlı yaşlı grupları için de uygulanabileceği düşünülmüş olup, YBIÇBGÖ'de yer alan maddelerin hem yaşlı hizmet kurumlarında kalan, evde-bakım hizmetlerinden yararlanan ya da ailesiyle birlikte yaşayan ya da yalnız yaşayan yaşlı bireylerin tamamına uygulanabilmesi bakımından uzman görüşü alınarak bazı değişiklikler yapılmıştır.

YBİÇBGÖ’nün doğrulayıcı faktör analizi sonuçlarının uyumuna ilişkin istatistikler Şekil 2'de sunulmuştur. YBİÇBGÖ'nün kuramsal yapısına ilişkin kurulan model Şekil 2'de görülmektedir. Şekil 2'deki standardize edilmiş değerler incelendiğinde ise tüm gözlenen değişkenlerin gizli değişkene olumlu katkıda bulunduğu belirtilmiştir. Gözlenen değişkenlerin gizil değişkene olan katkılarının düzeyini açıklayan standardize edilmiş $\mathrm{r}^{2}$ değerleri öz-bakım alt boyutunda 1. maddenin, yönelim bozukluğu alt boyutunda 14. maddenin, depresif/kayg1l duygudurum alt boyutunda 18 . maddenin, huzursuzluk verici davranış alt boyutunda 31 . maddenin, toplumdan uzaklaşma alt boyutunda ise 38. maddenin en çok katk1 sağladığını göstermiştir, bu sonuçlar madde test korelasyonu sonuçlarıla uyumluluk göstermektedir.

YBİÇBGÖ’niün doğrulayıcı faktör analizi sonuçlarının uyumuna ilişkin istatistikler Tablo 2'de verilmiştir. 


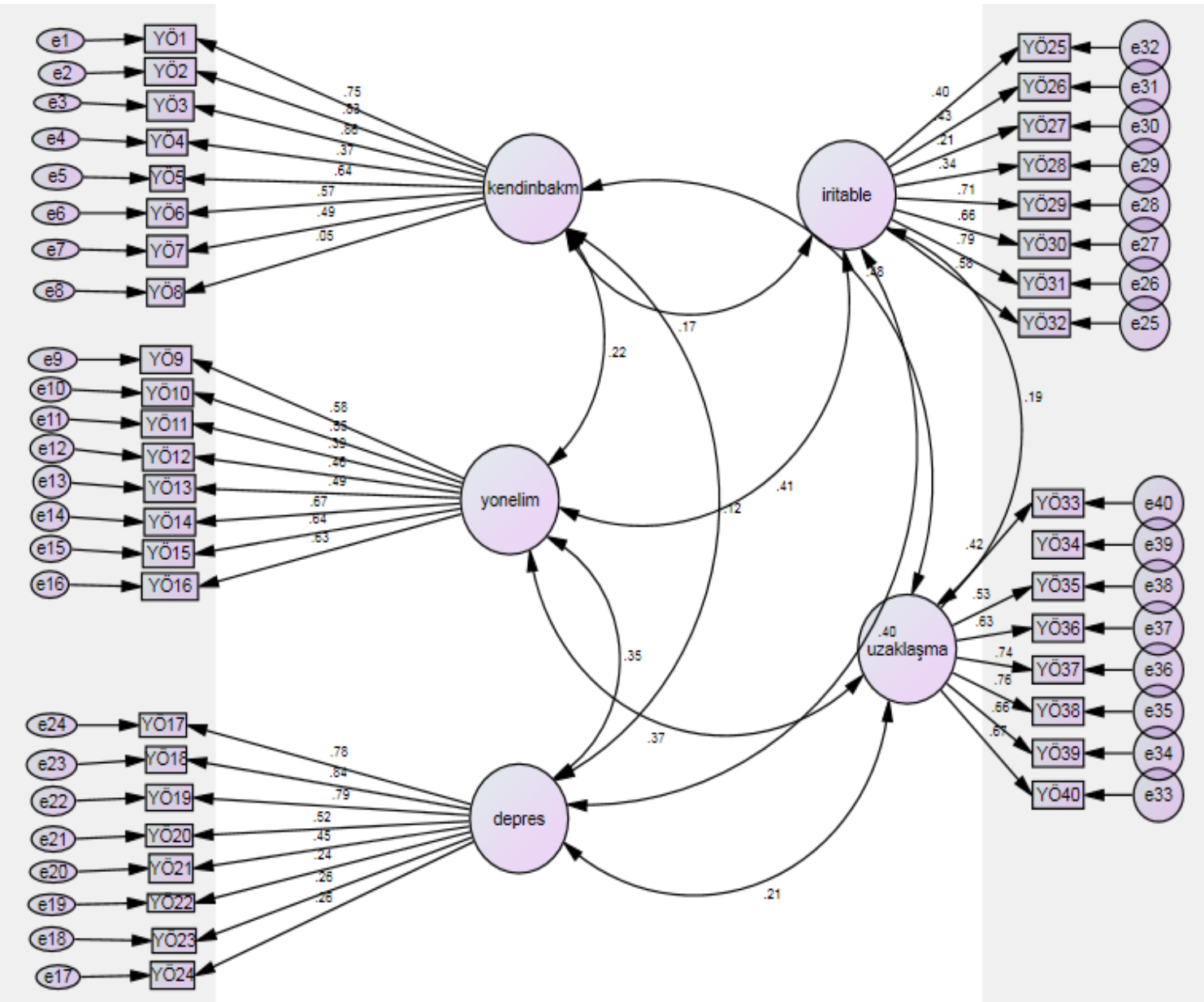

Şekil 2. YBİÇBGÖ’nün maddelerine uygulanan doğrulayıcı faktör analizi diyagramı

\begin{tabular}{|l|c|}
\hline Tablo 2. YBíÇBGÖ’nün Uyum İyiliği Testlerine (Goodness-of-Fit Indices) ilişkin değerler \\
\hline Uyum İyiliği Testlerine İlişkin Değerler & EGS Ölçeği \\
\hline Chi-Square & 1742.39 \\
\hline DF & 721 \\
\hline P-Value & $\mathrm{P}<.05$ \\
\hline CFI & 0.90 \\
\hline NFI & 0.84 \\
\hline AGFI & 0.87 \\
\hline IFI & 0.90 \\
\hline SRMR & 0.090 \\
\hline RMSEA & 0.083 \\
\hline 90\% C.I RMSEA & $0.078-0.087$ \\
\hline
\end{tabular}

Tablo 2'de verilen uyum iyiliği indeks sonuçlarına göre, model ve veri arasındaki uyum kabul edilebilir düzeydedir. İyi bir uyum indeksi olmayan Ki-kare değeri manidar bulunmuştur; ancak bu durum modeldeki parametre fazla olduğundan beklenen bir durumdur. Ki-kare değerinin serbestlik derecesine olan bağımlılı̆̆ını düzeltmek için bu değer serbestlik derecesine bölündüğünde, elde edilen sonuç ( ${ }^{2} / \mathrm{df}$ oran $2.40^{\prime} \mathrm{d} ı r$ ) model-veri uyumuna işaret etmektedir. Buna ek olarak yine model-veri uyumu göstergelerinden olan CFI (0.90),
NFI (0.84), AGFI (0.87) değerleri model ve veri uyumunu göstermektedir. Ayrıca, örneklemden bağımsız olarak SRMR değerinin olasılığını veren uyum indeksi IFI değeri 0.90 olarak belirlenmiştir. Ayrıca RMSEA değerinin \% 90 olasılıklı güven aralığının $0.078-0.087$ olduğu saptanmıştır. Son olarak modelin standartlaştırılmış hatalarına ilişkin model uyumunu veren SRMR değerinin (0.09) kabul edilebilir olduğu görülmektedir. Buradan hareketle YBIÇBGÖ'nün beş boyutlu yapısının güvenilir ve geçerli sonuçlar verebileceği sonucuna ulaşılabilir. 


\section{Madde Analizi}

Madde analizinde ayırıcılık gücü indeksi için madde-test korelasyonu hesaplanmıştır. Tablo 3'de YBİÇBGÖ'deki maddelerin madde-test korelasyonuna ilişkin bulgulara yer verilmiştir. Tablo 3 incelendiğinde ölçeğin alt boyutlarında yer alan her bir maddenin kabul edilebilir düzeyde madde-ölçek korelasyonu olduğu görülmektedir.

\begin{tabular}{|c|c|c|}
\hline Alt Boyutlar & Maddeler & $\begin{array}{c}\text { Madde-Ölçek } \\
\text { Korelasyonu }\end{array}$ \\
\hline \multirow{8}{*}{ 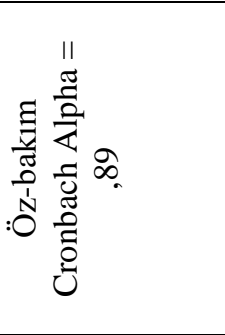 } & Giyim kuşam & ,79 \\
\hline & Banyo yapma & ,69 \\
\hline & Kişisel bakım & ,75 \\
\hline & Altına kaçırma & ,52 \\
\hline & Tuvalet kullanımı & ,78 \\
\hline & Fiziksel hareketlilik & ,75 \\
\hline & Yatağa yatma/yataktan kalkma & ,72 \\
\hline & Kisıtlayıcıların kullanımı & ,33 \\
\hline \multirow{8}{*}{ 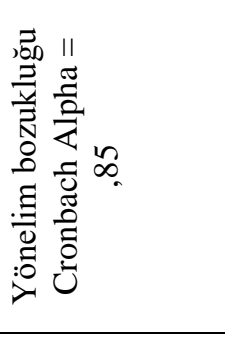 } & İletişimi anlama & ,67 \\
\hline & Konuşma & ,59 \\
\hline & Bina içinde yolunu bulma & ,43 \\
\hline & İnsanları tanıma & ,58 \\
\hline & Bulunduğu yerin farkında olma & ,60 \\
\hline & Zamanın farkında olma & ,73 \\
\hline & Yakın zamandaki olayları anımsama & ,65 \\
\hline & Önemli geçmiş olayları anımsama &, 55 \\
\hline \multirow{8}{*}{ 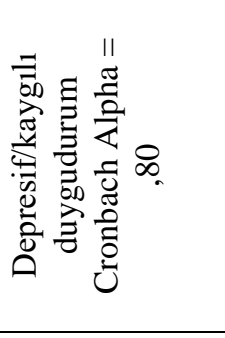 } & Mutsuz ve depresif görünüm & ,55 \\
\hline & Mutsuzluk ve depresyon bildiren konuşmalar & ,64 \\
\hline & Mutsuz ve depresif ses tonu & 62 \\
\hline & Endişeli ve kaygılı görünüm & ,57 \\
\hline & Endişe ve kaygı bildiren konuşmalar &, 60 \\
\hline & Ağlama &, 38 \\
\hline & Gelecek hakkında karamsarlık & ,43 \\
\hline & Kendisiyle aşırı meşgul olma & ,33 \\
\hline \multirow{8}{*}{ 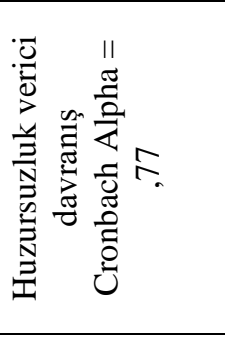 } & Bakım veren kişiler ile işbirliği & ,38 \\
\hline & Bakım veren kişilerin istem ve yönergelerine uyma & ,43 \\
\hline & Rahatsızlık verici ve huysuz davranış & ,29 \\
\hline & Engellenmeye karşı tepkiler & ,38 \\
\hline & Bakım veren kişilere sözlü saldırı & ,64 \\
\hline & Diğer insanlara sözlü saldırı &, 52 \\
\hline & Başkalarına fiziksel saldırı & ,64 \\
\hline & Diğer insanlarla münakaşa çıkarma &, 51 \\
\hline \multirow{8}{*}{ 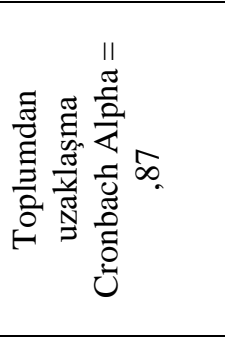 } & Yalnızlığı tercih etme & ,43 \\
\hline & Sosyal ilişkileri başlatma & ,56 \\
\hline & Sosyal ilişki kurma girişimlerine verilen karş1lık & ,68 \\
\hline & Diğer insanlarla arkadaşlik & 65 \\
\hline & Günlük olaylara ilgi & ,73 \\
\hline & D1ş çevrede olan olaylara ilgi & ,69 \\
\hline & Bir işle meşgul olma & ,65 \\
\hline & Başkalarına yardım etme & ,62 \\
\hline
\end{tabular}

Şöyle ki Öz-bakım Alt Ölçeği için en düşük maddeölçek korelasyonunun 0,33 ile "kısıtlayıcıların kullanımı" maddesinde ve en yüksek ise 0,79 ile "giyim kuşam" maddesinde olduğu anlaşılmaktadır. Yönelim Bozukluğu Alt Ölçeği için en düşük madde-ölçek korelasyonunun 0,43 ile "bina içinde yolunu bulma" maddesinde ve en yüksek ise 0,73 ile "zamanın farkında olma" maddesinde olduğu görülmektedir. Depresif/kaygılı Duygudurum Alt Ölçeği için en düşük madde-ölçek korelasyonunun 0,33 ile "kendisiyle aşırı meşgul olma" ve en yüksek ise 0,64 ile "mutsuzluk ve depresyon bildiren konuşmalar" maddesinde olduğu anlaşılmaktadır. Huzursuzluk verici davranış Alt Ölçeği için en düşük 
madde-ölçek korelasyonunun 0,29 ile "alınganlık ve huysuzluk" maddesinde ve en yüksek ise 0,64 ile "bakım veren kişilere sözlü saldırı" maddesinde olduğu görülmektedir. Toplumdan Uzaklaşma Alt Ölçeği için en düşük madde-ölçek korelasyonunun 0,43 ile "yalnızlığ yüksek ise "günlük olaylara ilgi" maddesinde olduğu görülmektedir.

\section{SONUÇ}

YBİÇBGÖ’yü oluşturan maddelerin alt ölçeklere dağılımının doğrulayıcı faktör analizi sonucunda orijinal ölçekteki dağılımla benzer olduğu saptanmıştır. Şöyle ki Helmes, Csapo ve Short ${ }^{18}$ tarafından geliştirilen orijinal ölçeğin alt ölçeklerinin Cronbach Alpha değerleri Öz-bakım 0,82; Yönelim Bozukluğu 0,87; Depresif/kaygılı Duygudurum 0,80; Huzursuzluk verici davranış 0,79 ve Toplumdan Uzaklaşma 0,78 iken; çalışmamızda alt ölçeklerin Cronbach Alpha değerleri Öz-bakım 0,89; Yönelim Bozukluğu 0,85; Depresif/kaygılı Duygudurum ,80; Huzursuzluk verici davranış 0,77 ve Toplumdan Uzaklaşma 0,87 bulunmuştur. Büyüköztürk madde-toplam korelasyonu 0.30 ve daha yüksek olan maddelerin bireyleri iyi derecede ayırt ettiği, $0.20-0.30$ arasında kalan maddelerin zorunlu görülmesi durumunda teste alınabileceği, 0.20'den daha küçük maddelerin ise teste alınmaması gerektiğini belirtmektedir. ${ }^{20}$ Ölçekte yer alan maddelerin korelasyon katsayılarının "alınganlık ve çabuk heyecanlanma" maddesi hariç $(0,29)$ kalan maddelerin hepsinin de 0.30'dan yüksek olması ayırıcı olduğunu göstermektedir. ${ }^{21}$ Dolayısıyla ölçeğin Türkçe formunun Türkiye'de kurum bakım hizmeti alan, evde sağlık hizmeti alan, ailesiyle birlikte yaşayan ya da yalnız başına yaşayan yaşlı bireylerin bilişsel, psikolojik ve sosyal işlevselliklerini belirlemede ve çok boyutlu değerlendirmede kullanılabileceği düşünülmektedir.

\section{KAYNAKLAR}

1. Tufan İ. Geronto-Sosyoloji. Toplum ve Sosyal Hizmet Dergisi 2004; 15 (1), 75-84.

2. Kalınkara V. Temel gerontoloji: yaşlılık bilimi. Ankara: Nobel Akademik Yayıncılık; 2011. p. 7-9.

3. Chappell NL. Arrangement and sources of caregiving. Journal of Gerontology 1991; 46:1,1-8.

4. Danış, MZ. Yaşlıların evde bakım gereksinimleri ve evde bakıma ilişkin düşünceleri. Ankara: Seçkin Yayınevi; 2004. p.35-44.

5. Siebert DC, Mutran EJ, Reitzeu DC. Friendship and social support: The importance of role identity to aging adults. Social Work 1999; 44 (6): 522-533.
6. Burke MM, Laramine LA. Health assessment and health maintenance screening in primary care of the older adult: a multidisciplinary approach. Mosby, St. Louis. 2000; 35-60.

7. Özmete E. Hwalek-Sengstock yaşlı istismarı tarama testi: Türkçeye uyarlama çalışması. Anadolu Psikiyatri Dergisi, 201617 (Ek.1): 4552.

8. Tuncay T, Duyan, V. Turkish adaptation of the geriatric social work competency scale in a group of social work bachelor students. Turkish Journal of Geriatrics 2015; 18 (1): 60-67.

9. Akın B, Emiroğlu ON. Evde yaşayan yaşlılarda sosyal destek yapısı, sağlı durumu ve yetiyitimi ilişkisi, Geriatri Dergisi-Turkish Journal of Geriatrics 2006; 9(3): 170-176.

10. Devlet Planlama Teşkilatı (2007). Türkiye'de yaşliların durumu ve yaşlanma ulusal eylem planı. Yayın no. DPT: 2741. Erişim tarihi: 23.03.2017 http://ekutup.dpt.gov.tr/nufus/yaslilik/eylempla .pdf

11. Hocaoğlu Ç. Yaşlilarda distimik bozukluk. Geriatri ve Geriatrik Nöropsikiyatri Dergisi 2010; 2: 36-48.

12. Birleşmiş Milletler, (2002). Ekonomi ve sosyal işler dairesi nüfus bölümü: Dünya nüfus yaşlanması 1950-2050. Erişim tarihi: 23.03.2017

http://www.un.org/esa/population/publications/ worldageing19502050/pdf/200turke.pdf

13. Tufan İ. Yaşlanan dünya'da bir delikanlı: Türkiye. Toplum ve Sosyal Hizmet Dergisi 2001; 12 (3): 27-49.

14. Türkiye İstatistik Kurumu, (2016). Adrese Dayalı Kayıt Sistemi. Erişim tarihi: 23.03.2017 www.tuik.gov.tr

15. Bozdemir N, Özeren A, Koç F, Özcan S, Güzel R, Göçmen C. ve ark. Çukurova Üniversitesi Tıp Fakültesi yaşlı bireye multidisipliner yaklaşım modülü: hazırlık aşaması. Turkish Journal of Family Medicine \& Primary Care 2011 March; 5(1): 1-8.

16. Hersch EL, Csapo KG, Palmer RB. Development of the London psychogeriatric rating scale. London Psychiatric Hospital Research Bulletin 1978; 1: 3-21.

17. Hersch EL, Kral VA, Palmer RB. Clinical value of the London psychogeriatric rating scale. Journal of the American Geriatrics Society 1978; 26: 348-354.

18. Helmes E, Csapo KG, Short JA. Standardization and validation of the multidimensional observation scale for elderly subjects (MOSES). Journal of Gerontology 1987; 42, (4): 395-405.

19. Sturmey P, Tsouris JA, Patti P. The psychometric properties of the multidimensional observation scale for elderly subjects (MOSES) in middle aged and older populations of people with mental retardation. 
International Journal of Geriatric Psychiatry 2003; 18: 131-134. doi: 10.1002/gps.730.

20. Büyüköztürk Ş. Veri analizi el kitabı. Ankara: PEGEM A Yayıncilık; 2004. p. 195.
21. Özçelik DA. Test hazırlama kılavuzu. Ankara: PEGEM A Yayıncılık; 2010. p. 135. 


\section{Ek 1. YAŞLI BİREYLER ICÇIN ÇOK BOYUTLU GÖZLEM ÖLÇEĞI}

Lütfen tüm soruları yanıtladığınızdan emin olunuz.

Her bir soru için, geçen hafta yaşlının gün içindeki davranışını en iyi tanımlayan seçeneği seçiniz. Parantez içinde verilen örnekler, karar almanızda size yardımcı olacaktır.

Yanıt formu üzerinde sadece tek bir seçenek işaretleyiniz.

1. GIYIMM KUŞAM

Geçen haftanın çoğu gününde, yaşlı:

1. Bir başkasının yardımına gereksinim duymaksızın giyinmeye başladı ve giyindi.

2. Yalnızca küçük bir yardımla giyindi. (Örneğin, giyeceği giysiler hazırlandı ya da giyinmesi gerektiği hatırlatıldi)

3. Kısmen kendi başına giyindi, ancak çoğunlukla bir başkasının yardımına gereksinim duydu.

4. Ya tümüyle bir başkası tarafindan giydirildi ya da pijamalarıyla kaldı.

2. BANYO YAPMA (Banyo ve duşu içerir)

Geçen hafta içinde banyo yaparken, yaşlı:

1. Bir başkasının yardımına gereksinim duymaksızın banyo hazırlıklarını yaptı ve banyosunu yaptı.

2. Yalnızca küçük bir yardımla banyo yaptı. (Örneğin, banyo öncesinde sabunun kendisine verilmesi, musluğun açılması, havluların hazırlanması veya banyo yapması için uyarılması gerekti)

3. Kısmen kendi başına banyo yaptı, ancak çoğunlukla bir başkasının yardımına gereksinim duydu. (Örneğin, küvete veya duşa girerken ve çıkarken fiziksel yardıma gereksinim duydu veya bir başkası tarafından vücudunun bazı kısımlarının yıkanması ya da havluyla kurulanması gerekti)

4. Banyosu tamamen bir başkası tarafindan yaptırıldı (Yatakta yapılan yıkamalar dâhil)

3. KIŞSiSEL BAKIM (Saç, tırnak, diş bakımı ve tıraş olma dâhil. Giyim-kuşam ve banyo yapma hariç) Geçen hafta içinde, yaşlı:

1. Kişisel bakımının tamamını bir başkasının yardımına gereksinim duymaksızın yaptı.

2. Bazı kişisel bakım işlerini kendi başına yaptı, ancak bir bölümü için bir başkasının yardımına ya da gözetimine gereksinim duydu.

3. Kendi bakımının bir kısmına yardımcı oldu, fakat çoğunlukla kişisel bakımının tüm yönleri için bir başkasının yardımına gereksinim duydu.

4. Kişisel bakımının tamamı bir başkası tarafından yapıldı.

4. ALTINA KAÇIRMA (İdrar ya da dışkı kaçırma dâhil)

Geçen hafta içinde yaşlı hangi sıklıkta idrar ya da dışkı kaçırdı?

1. Hiç

2. Yalnızca geceleri

3. Gündüzleri ara sıra

4. Gündüzleri sıklıkla (günde bir defadan daha fazla)

5. TUVALET KULLANIMI

Geçen hafta içinde, tuvaleti kullandığı zamanların çoğunda, yaşlı:

1. Bir başkasının yardımına gereksinim duymaksızın tuvalete gitti ve tuvaleti gerektiği gibi kullandı.

2. Yalnızca küçük bir yardımla tuvaleti kendi başına kullandı (Örneğin, tuvalete gitmesi ya da tuvalet sonrası temizliğini yapması hatırlatıldı veya ara sıra tuvaleti kirletti)

3. Tuvaletini kendi başına yapmaya çalıştı, ancak çoğunlukla bir başkasının yardımına gereksinim duydu. (örneğin, pantolonunu indirirken, tuvalet sonrası temizlik yaparken ve oturup kalkarken yardıma gereksinim duydu)

4. Tuvaleti tamamen bir başkası tarafından yaptırıldı. (Tuvalete bir başkası tarafından oturtulup kaldırıldı. Ördek ya da lazımlık, sonda ve kolostomi kullanımı dâhil)

6. FIZIKSSEL HAREKETLILIK

Geçen haftanın çoğu gününde, yürüyüşe ya da gezmeye çıktığı zaman yaşlı:

1. Herhangi bir yardıma gerek kalmaksızın yürüyüş yaptı.

2. Mekanik yardımla kendi başına yürüdü. (Örneğin, baston, kolluk değneği ve yürümeye yardımcı cihazlar ile kendi başına yürüdü ya da tekerlekli sandalyeyi kendi gücüyle sürdü)

3. Bir başkasının fiziksel yardımıyla yürüdü.

4. Yatağa ya da koltuğa bağlı kaldı. (Koltuğa bağlı kalmak deyimi, gün içinde yataktan koltuğa nakledilen ancak bunun dışında tamamen hareketsiz kalan yaşlıları tanımlamak için kullanılmışıı)

7. YATAĞA YATMA/YATAKTAN KALKMA

Geçen haftanın çoğu gününde, yaşlı:

1. Herhangi bir fiziksel yardım olmaksızın, yatağa kendi başına yatıp kalkabildi.

2. Bir başkasına gereksinim duymaksızın, ancak bazı araçların yardımıyla yatağına yattı ve yatağından kalktı (Örneğin, trapez ya da kayma tahtasını kendisi kullanarak) 
3. Bir başkasının fiziksel yardımıyla yatağa yatıp yataktan kalktı.

4. Bütün gün yatakta kaldı.

8. KISITLAYICILARIN KULLANIMI

(Örneğin, yatak tırabzanı, yumuşak bağlar, geriyatrik sandalye kullanımı)

Geçen hafta gün içinde, bu kısıtlayıcılar yaşlı için ne sıklıkta kullanıldı?

1. Hiç

2. Nadiren (bir-üç gün, yalnızca kısa süreyle)

3. Ara sıra (ya kısa sürelerle 3 günden fazla ya da günün çoğunluğunda olmak üzere 1-3 gün boyunca)

4. Sik sık (günün çoğunluğunda olmak üzere 3 günden fazla)

9. İLETIŞiMİI ANLAMA

(Sözlü, yazılı ya da jestlerle)

Geçen hafta içinde yaşlıyla iletişim kurduğunuzda çoğu kez, yaşlı:

1. Sizi net olarak anladı

2. Yalnızca kısa iletileri anladı (kısa cümleler ya da hareketler gibi)

3. Ancak tekrar edildiğinde kısa iletileri anladı.

4. Hiçbir iletiyi anlamadı.

10. KONUŞMA

Geçen hafta içinde, konuştuğu zamanların çoğunda yaşlının konuşması:

1. Tutarlı ve mantıklıydı.

2. Mantıklı başladı, ancak konuşurken konunun etrafinda gezinip durdu.

3. Kulağa tutarlı geldi, ancak söyledikleri konuyla ilgisizdi. (Örneğin, konuşması, sorulan soruyla ya da yaşanan olayla ilgili değildi).

4. Çok az anlam ifade etti (Örneğin, sözcüklerin karışması, anlamsız cümleler ya da anlamsız sesler).

5. Soru geçerli değil - yaşlı geçen hafta hiç konuşmadı.

11. BINA IÇCiNDE YOLUNU BULMA

(Örneğin, kendi odasını, banyoyu veya yemek salonunu bulma becerisi)

Geçen hafta gün içinde yaşlı, yaşadığı binada yolunu bulmada ne kadar sıklıkla dezoryante ve konfüze haldeydi?

1. Hiç

2. Nadiren (hafta boyunca sadece 1-3 kez)

3. Ara sıra (ya günde 1-2 kez olmak üzere 3 günden fazla ya da günde birkaç kez olmak üzere 1-3 gün boyunca)

4. Sık sık (günde birkaç kez olmak üzere 3 günden fazla)

5. Soru geçerli değil - yaşlı geçen hafta bina içinde herhangi birinin yardımı olmaksızın hiç dolaşmadı.

12. INSANLARI TANIMA

Geçen hafta içindeki günlerin çoğunda, yaşlı:

1. Birçok insanı tam olarak tanıdı.

2. Bir ya da iki kişiyi tam olarak tanıdı.

3. İnsanları ayırt edebildi, ancak hiçbirini tam olarak tanıyamadı.

4. İnsanların hiçbirini tam olarak tanıyamadı ya da ayırt edemedi.

13. BULUNDUĞU YERİN FARKINDA OLMA

Geçen hafta boyunca, yaşlı:

1. Yaşadığı yeri tam olarak biliyordu. (Yaşadığı yeri, hangi şehirde veya ilçede olduğunu biliyordu)

2. Yaşadığ yerin nasıl bir yer olduğunu biliyordu, ancak mahallesini karıştırıyordu.

3. Ara sıra yaşadığı yerin neresi olduğunu anlıyor gibi görünüyordu, ancak diğer zamanlarda bunu karıştırıyordu.

4. Yaşadığı yerin neresi olduğunu karıştırıyordu. (Örneğin, evde mi yoksa başka bir yerde mi olduğunu bilemiyordu)

5. Bu konuda bilgi elde edilemedi. Yaşlı ile uygun bir iletişim kurulamadı.

14. ZAMANIN FARKINDA OLMA

Geçen hafta içindeki günlerin çoğunda, içinde bulunulan (a) yılın (b) mevsimin (c) günün zamanının (sabah, öğleden sonra ya da akşam yemeği sonrası gibi) farkında olup olmadığı dikkate alındığında, yaşlı:

1. Üçünün de (yıl, mevsim ve günün zamanı) farkındaydı.

2. Bunlardan ikisinin farkındaydı.

3. Bunlardan birisinin farkındayd1.

4. Üçünü de karıştırdı.

5. Bu konuda bilgi elde edilemedi. Yaşlı ile uygun bir iletişim kurulamadı.

15. YAKIN ZAMANDAKI OLAYLARI ANIMSAMA

(Geçen hafta olan eğlence, yemek, ziyaret gibi günlük olaylara dair)

Geçen hafta boyunca, yaşl1: 
1. Yakın geçmişe ait olayların çoğunu net olarak hatırlayabildi.

2. Yakın geçmişe ait olayların çoğunu belli belirsiz hatırlayabildi.

3. Yakın geçmişe ait olayların bir kısmını hatırlayabildi, ancak diğerlerini tümüyle unuttu.

4. Olayların çoğunu, meydana geldikten birkaç dakika sonra unutmuş gibiydi.

5. Bu konuda bilgi elde edilemedi. Yaşlı ile uygun bir iletişim kurulamadı.

16. ÖNEMLİ GEÇMIŞ OLAYLARI ANIMSAMA

(Örneğin doğum tarihi, geçmişteki işi/mesleği, aile üyelerinin isimleri ve halen hayatta olup olmadıkları gibi) Geçen hafta boyunca, yaşlı:

1. Uzak geçmişe ait olayların çoğunu kolaylıkla ve doğru olarak hatırlayabildi.

2. Uzak geçmişe ait olayların çoğunu biraz çabayla doğru olarak hatıllayabildi.

3. Uzak geçmişe ait olayların bir kısmını hatırlayabildi, ancak diğerlerini unuttu.

4. Geçmiş yaşamındaki çoğu olayla hakkında kafası karışıktı.

5. Bu konuda bilgi elde edilemedi. Yaşlı ile uygun bir iletişim kurulamadı.

17. MUTSUZ VE DEPRESIF GÖRÜNÜM

(Örneğin, kasvetli, mutsuz, kederli gibi görünme. Sıkılmış, kayıtsız, düşünceli ya da endişeli görünümleri dikkate almayınız)

Geçen hafta boyunca yaşlı hangi sıklıkta mutsuz ve depresif görünüyordu?

1. Hic

2. Nadiren (sadece kısa sürelerde olmak üzere 1-3 gün)

3. Ara sıra (ya günde 1-2 kez olmak üzere 3 günden fazla ya da günde birkaç kez olmak üzere 1-3 gün boyunca)

4. Sık sık (günün çoğunluğunda olmak üzere 3 günden fazla).

5. İfade edemedi - yaşlının yüzüne sıkıntılı bir ifade veren yüz felci veya fiziksel sorunları var.

18. MUTSUZLUK VE DEPRESYON BILLDIREN KONUŞMALAR YAPMA

(Mutsuz veya depresif olduğunu ya da başka bir yerde bulunmayı istediğini söylemek. Kendisine sunulan bakım hakkındaki şikâyetlerini dikkate almayınız. Ayrıca kendisini endişeli hissettiğine dair konuşmalarını da hesaba katmayınız.)

Geçen hafta içinde, yaşlı hangi sıklıkla mutsuz ya da depresif olduğunu belirten şeyler söyledi (ya da yazdı)?

1. Hiç

2. Nadiren (hafta boyunca sadece 1-3 kez)

3. Ara sıra (ya günde 1-2 kez olmak üzere 3 günden fazla ya da günde birkaç kez olmak üzere 1-3 gün boyunca)

4. Sık sık (günde birkaç kez olmak üzere 3 günden fazla. Ayrıca bu seçeneğe, ölmek istediğini söyleyen herhangi bir yaşlıyı da dâhil ediniz)

5. Soru geçerli değil - yaşlı geçen hafta konuşmadı (ya da yazmadı).

19. MUTSUZ VE DEPRESIF SES TONU

(Mutsuzluk veya depresyonu çağrıştıran bir ses tonunda konuşmak veya inlemek ya da iç çekmek gibi mutsuzluk ifade eden sesler çıkarmak. Kızgın veya endişeli ses tonunu ya da akut ağrıdaki ses tonunu dikkate almayınız).

Geçen hafta içerisinde yaşlı hangi sıklıkta mutsuz ve depresif bir ses tonu kullandı?

1. Hiç

2. Nadiren (yalnızca kısa sürelerle olmak üzere 1-3 gün boyunca)

3. Ara sıra (ya kısa sürelerle olmak üzere 3 günden fazla ya da günün çoğunda 1-3 gün boyunca)

4. Sik sık (günün çoğunda olmak üzere 3 günden fazla)

5. Soru geçerli değil - yaşlı geçen hafta konuşmadı ya da hiçbir ses çıkarmadı.

20. ENDİSELİ VE KAYGILI GÖRÜNÜM

(Mutsuz ve depresif görünümü dikkate almayınız)

Geçen hafta boyuncu yaşlı hangi sıklıkta endişeli, gergin ve kaygılı görünüyordu?

1. Hiç

2. Nadiren (sadece kısa sürelerde olmak üzere 1-3 gün)

3. Ara sıra (ya günde 1-2 kez olmak üzere 3 günden fazla ya da günde birkaç kez olmak üzere 1-3 gün boyunca)

4. Sik sık (günün çoğunluğunda olmak üzere 3 günden fazla).

21. ENDIŞE VE KAYGI BİLDIREN KONUŞMALAR YAPMA

(Çeşitli konular hakkında endişeli olduğu yolunda konuşmak. Mutsuz olduğu ile ilgili konuşmaları hesaba katmayınız)

Geçen hafta sırasında yaşlı, hangi sıklıkla bir konu hakkında endişeli veya kaygıllı olduğunu belirten şeyler söyledi (ya da yazdi)?

1. Hiç

2. Nadiren (hafta boyunca sadece 1-3 kez) 
3. Ara sıra (ya günde 1-2 kez olmak üzere 3 günden fazla ya da günde birkaç kez olmak üzere 1-3 gün boyunca)

4. Sik sık (günde birkaç kez olmak üzere 3 günden fazla

5. Soru geçerli değil - yaşlı geçen hafta konuşmadı (ya da yazmadı).

22. AĞLAMA

(İnleme, iç çekme ve bağırmaları hesaba katmayınız.)

Geçen hafta içerisinde yaşlı hangi sıklıkta ağladı?

1. Hiç

2. Nadiren (yalnızca kısa sürelerle olmak üzere 1-3 gün)

3. Ara süre (ya yalnızca kısa sürelerle olmak üzere 3 günden fazla ya da uzun sürelerle olmak üzere 13 gün boyunca)

4. Sik sik (uzun sürelerle olmak üzere 3 günden fazla)

23. GELECEK HAKKINDA KARAMSARLIK

(Geleceğin ümitsiz veya dayanılmaz olduğu ya da işlerin daha iyiye gitmeyeceği hakkında konuşmak)

Geçen hafta içinde, yaşlı geleceği hakkında kendisini karamsar hissettiğini gösterecek şeyleri ne kadar sıklıkta söyledi veya yazdı?

1. Hiç

2. Nadiren (hafta boyunca sadece 1-3 kez)

3. Ara sıra (ya günde 1-2 kez olmak üzere 3 günden fazla ya da günde birkaç kez olmak üzere 1-3 gün boyunca)

4. Sik sık (günde birkaç kez olmak üzere 3 günden fazla.

5. Soru geçerli değil - yaşlı geçen hafta konuşmadı (ya da yazmadı).

24. KENDISIYYLE AȘIRI MEŞGUL OLMA

Geçen hafta içinde yaşlı, çok üzüntülü veya kendi sorunlarıyla meşgul olduğundan dolayı, kendi başına gelen veya etrafinda olan olaylara odaklanmada hangi sıklıkla sorun yaşadı?

1. Hiç

2. Nadiren (hafta boyunca sadece 1-3 kez)

3. Ara sıra (ya günde 1-2 kez olmak üzere 3 günden fazla ya da günde birkaç kez olmak üzere 1-3 gün boyunca)

4. S1k sık (günde birkaç kez olmak üzere 3 günden fazla.

25. BAKIM VEREN KIŞ̧iLER İLE İŞBİRLİ̈̆̇

(Beslenme, banyo yapma, kişisel bakım ve ilaç alma gibi konularda işbirliği)

Geçen haftanın çoğu gününde, hemşire ve bakım personeli ile etkileşimde bulunduğunda yaşl1:

1. Kendi bakımı için aktif olarak işbirliğinde bulundu. (mümkün olduğunda kendi bakımına katılmaya ve yardım etmeye çalışı)

2. Kendi bakımı için pasif olarak işbirliği yaptı. (kendi bakımının yapılmasına sessizce izin verdi)

3. Bakım girişimlerine az da olsa direnç gösterdi. (başlangıçta tartıştı, mızmızlandı ya da fiziksel direnç gösterdi, ancak hemen sonra bakım yapılmasını kabul etti)

4. Bakım girişimlerine üst düzeyde direnç gösterdi. (Yaşlıyla işbirliği yapmak gerçekten çok zordu)

26. BAKIM VEREN KISSILERIN İSTEM VE YÖNERGELERINEE UYMA

Geçen hafta içinde, onunla ilgilenen kişilerin istem ve yönergelerinin çoğuna yaşlı:

1. Herhangi bir direnç veya kızgınlık olmaksızın uydu.

2. Direnç göstermeksizin uydu, ancak sessiz bir kızgınlık vardı. (Örneğin, kısık sesle söylenmeler ya da hoş olmayan bakışlar)

3. İşbirliği yapmadan önce tartışı veya fiziksel direnç gösterdi.

4. Direnç gösterdi ve nihayetinde fiziki güç kullanılmak zorunda kalındı.

5. Yaşlı tarafından anlaşılmadı. (Zihinsel ya da fiziksel olarak ileri derecede engelli olduğu için basit istem ve yönergelerin verilemediği yaşlıları bu seçeneğe dahil ediniz)

27. HUZURSUZLUK VERICII DAVRANIŞ YA DA HUYSUZLUK

Geçen hafta içinde yaşlı, hangi sıklıkta alıngan ve huysuzdu?

1. Hiç

2. Nadiren (yalnızca kısa sürelerle olmak üzere 1-3 gün)

3. Ara süre (ya yalnızca kısa sürelerle olmak üzere 3 günden fazla ya da günün çoğunda olmak üzere 1-3 gün boyunca)

4. Sık sık (günün çoğunda olmak üzere 3 günden fazla)

28. ENGELLENMEYE KARŞI TEPKILER

(İstekleri reddedildiğinde veya bir şey için beklemesi gerektiğinde, istismar edici ya da şikayetleşerek tepki gösterme)

Geçen hafta sırasında yaşlı engellenme yaşadığında hangi sıklıkta sükûnetini kaybetti?

1. Hiç 
2. Nadiren (hafta boyunca sadece 1-3 kez)

3. Ara sıra (ya günde 1-2 kez olmak üzere 3 günden fazla ya da günde birkaç kez olmak üzere 1-3 gün boyunca)

4. Sik sık (günde birkaç kez olmak üzere 3 günden fazla).

29. BAKIM VEREN KISŞILERE SÖZLÜ SALDIRI

(Bağırma, küfretme, beddua etme, tehdit etme dahil)

Geçen hafta sırasında, yaşlı ne kadar sıklıkta bakım veren kişilere sözlü saldırıda bulundu?

1. Hiç

2. Bazen

3. Sik sık (günde en az $1 \mathrm{kez}$ olmak üzere 3 günden fazla) "Yapmak istemediği bir şeyi yapması söylendiğinde"

4. Sık sık (günde en az 1 kez olmak üzere 3 günden fazla) "Hiçbir kışkırtma ya da neden olmaksızın"

5. Soru geçerli değil - yaşlı geçen hafta konuşmadı ya da hiçbir ses çıkarmadı.

30. DİĞER İNSANLARA SÖZLÜ SALDIRI

(Bağırma, sövüp sayma, beddua etme, tehdit etme)

Geçen hafta sırasında, yaşlı ne kadar sıklıkla diğer insanlara sözlü olarak saldırıda bulundu?

1. Hiç

2. Bazen

3. Sik sık (günde en az 1 kez olmak üzere 3 günden fazla) "Diğer yaşlılar kendisiyle zıtlaştığında"

4. Sik sik (günde en az $1 \mathrm{kez}$ olmak üzere 3 günden fazla) "Hiçbir belirgin provokasyon ya da neden olmaksızın"

5. Soru geçerli değil - yaşlı geçen hafta ya hiç konuşmadı ya da diğer insanlarla ulaşma imkanı yok.

31. BAŞKALARINA FİZIKSSEL SALDIRI

(Bakım verenlere veya diğer insanlara vurma ya da itip kakma)

Geçen hafta içinde yaşlı, herhangi birine hangi sıklıkta fiziksel saldırıda bulundu?

1. Hiç

2. Bir kez, kışkırtıldıktan sonra

3. Bir kez, bir neden ya da kışkırtma olmaksızın

4. Birden çok (diğerlerine saldırmasını engellemek için önlem alınan yaşlıları bu gruba dahil ediniz)

5. Soru geçerli değil - yaşlı fiziksel olarak herhangi birine saldırabilecek durumda değil.

32. DİĞER İNSANLARLA MÜNAKAŞA ÇIKARMA

Geçen hafta içinde yaşlı, hangi sıklıkla başka biriyle münakaşa başlattı ya da kışkırttı?

1. Hiç

2. Nadiren (hafta boyunca 1-3 kez)

3. Ara sıra (ya günde 1-2 kez olmak üzere 3 günden fazla ya da günde birkaç kez olmak üzere 1-3 gün boyunca)

4. Sık sık (günde birkaç kez olmak üzere 3 günden fazla).

5. Soru geçerli değil - yaşlı diğer insanlara erişim olanağına sahip değildi.

33. YALNIZLIĞI TERCIHH ETME

(Kendi başına kalma)

Geçen hafta içinde yaşlı, fiziksel bakım olmadığı zamanlarda yalnız başına kalmayı tercih ediyor izlenimi verdi mi?

1. Hayır. Yaşlı - eğer mevcutsa - birileriyle birlikte olmaktan her zaman zevk aldı.

2. Birileriyle birlikte olma ya da yalnız kalma durumuna kayıtsız göründü.

3. Yaşlı, en azından zamanının bir kısmında birileriyle birlikte olmaya aktif olarak hevessiz/isteksiz kaldi.

4. Çoğu zaman birileriyle birlikte olmaya aktif olarak hevessiz/isteksiz kaldı.

34. SOSYAL İLIŞKILERİ BAŞLATMA

(Konuşarak, jestlerle ya da gülümseyip ilk adımı atarak ya da yaklaşarak)

Geçen hafta içinde, yaşlı:

1. Sıklıkla "Hem bakım veren kişilerle hem de diğer insanlarla olan sosyal ilişkilerì" kendisi başlattı. (günde birkaç kez 3 günden fazla)

2. Sıklıkla "Ayrı ayrı olmak üzere ya bakım veren kişilerle ya da diğer insanlarla olan sosyal ilişkileri”" kendisi başlattı. (günde birkaç kez 3 günden fazla)

3. Ayrı ayrı olmak üzere ya bakım veren kişilerle ya da diğer insanlarla olan sosyal ilişkileri”" zaman zaman kendisi başlattı.

4. Bakım veren kişilerle veya diğer insanlarla hiçbir zaman sosyal ilişki başlatmadı.

35. SOSYAL İLIȘKI KURMA GIRIŞIMLERINE VERILEN KARȘILIK

(Yalnızca yönergeleri takip eden ya da sosyal iletilere sadece bakarak verilen karşılıkları dikkate almayın) 
Geçen hafta içinde yaşıı, başkaları tarafından yapılan sosyal ilişki kurma girişimlerine hangi sıklıkla karşılık verdi?

1. Çoğu zaman karşılık verdi ve ilişkinin sürmesi için çaba sarf etti. (Örneğin, sohbeti sürdürerek ya da o kişiyi dinlemeye devam ederek)

2. Çoğu zaman kısaca karşılık verdi. (Örneğin, sadece soruya yanıt vererek, başını sallayarak ya da gülümseyerek, ancak ilişkinin sürmesi için çaba harcamadan)

3. Yalnızca bazı zamanlarda (diğerlerinin sosyal ilişki kurma çabalarının yarısından daha az)

4. Hiç

36. DİĞER İNSANLARLA ARKADAŞLIK

Geçen hafta içinde yaşli,

1. Birden fazla kişiyle yakın arkadaşlık yaptı. (Bu gerçek bir ilişki kastedilmektedir)

2. Sadece bir kişiyle ile yakın arkadaşlık yaptı.

3. En azından bir kişiyle tesadüfen arkadaşlık kurdu. (Örneğin, birisiyle bir süre birlikte oldu, ancak gerçek bir ilişki kurmadı)

4. Hiçbir kişiyle, hiçbir şekilde arkadaşlık yapmadı.

5. Soru geçerli değil - yaşlı diğer insanlara erişim olanağına sahip değildi.

37. GÜNLÜK OLAYLARA İLGİ

(Örneğin, çevresinde olan bitenleri izleyerek, dinleyerek veya tepki vererek)

Geçen hafta içinde yaşlı çevresinde olan bitenlere hangi sıklıkla aktif olarak dikkat gösterdi?

1. Siklıkla (günün çoğunluğunda 3 günden fazla)

2. Ara sıra (ya kısa sürelerle olmak üzere 3 günden fazla ya da günün çoğunda 1-3 gün boyunca)

3. Nadiren (yalnızca kısa sürelerle 1-3 gün boyunca)

4. Hiç

38. DIŞ ÇEVREDE OLAN OLAYLARA İLGİ

(Örneğin, ailesinin ve yanında olmayan arkadaşlarının yaptığı etkinliklere veya haberlere ya da sporla ilgili haberlere ilgi göstermek)

Geçen hafta içinde yaşlı, kaldığı yerin dışında olan olaylara hangi sıklıkla ilgi gösterdi?

1. Her gün düzenli bir şekilde

2. Bazı günler

3. Nadiren (örneğin ailesine az miktarda ilgi gösterebildi, ancak bu sadece ailesinin yaşlıya yapacağ ziyaretlerle ilgiliydi)

4. Hiç

39. BİR İŞLE MEŞGUL OLMA

(Kendi başına okuyarak, televizyonu dikkatle izleyerek veya radyo dinleyerek, hobileriyle uğraşarak, sohbet ederek, yürüyüş yaparak boş zamanları değerlendirme. Organize edilen eğlence etkinliklerini hesaba katmayınız)

Geçen hafta içinde yaşl1, hangi sıklıkta kendi başına bir işle meşgul oldu?

1. Siklıkla (günün çoğunluğunda 3 günden fazla)

2. Ara sıra (ya günde 1-2 kez olmak üzere 3 günden fazla ya da günde birkaç kez olmak üzere 1-3 gün boyunca)

3. Nadiren (yalnızca kısa sürelerle 1-3 gün boyunca)

4. Hiç

40. BAŞKALARINA YARDIM ETME

(Başka bir kişiye ilgi duymayı yansıtıyor izlenimi veren her türlü yardımı dahil ediniz. Örneğin, diğer insanlara fiziksel olarak yardım ederek, onları rahat ettirerek veya eğlendirerek)

Geçen hafta içinde yaşlı, ne kadar sıklıkla diğer yaşlılara gönüllü olarak yardım etti?

1. Siklıkla (günün çoğunluğunda 3 günden fazla)

2. Ara sıra (ya günde 1-2 kez olmak üzere 3 günden fazla ya da günde birkaç kez olmak üzere 1-3 gün boyunca)

3. Nadiren (yalnızca kısa sürelerle 1-3 gün boyunca)

4. Hiç

Soru geçerli değil - yaşlı ya fiziksel olarak hareket edebilecek durumda değil (hareket edebilmek için başkalarının yardımına ihtiyacı var) ya da çoğu gün kısıtlama altında. 